\title{
ОСОБЛИВОСТІ СТРУКТУРНОї ПЕРЕБУДОВИ СУДИН ГЕМОМІКРОЦИРКУЛЯТОРНОГО РУСЛА ДВАНАДЦЯТИПАЛОЇ КИШКИ ПРИ ОБТУРАЦІЙНОМУ ХОЛЕСТАЗІ
}

\author{
○М. С. Гнатюк, Л. В. Татарчук, С. О. Грабчак \\ ДВНЗ «Тернопільський державний медичний університет імені І. Я. Горбачевського МОЗ України»

\begin{abstract}
РЕЗЮМЕ. У роботі наведено результати експериментального вивчення особливостей структурної перебудови судин гемомікроциркуляторного русла дванадцятипалої кишки при обтураційному холестазі. В результаті проведеного дослідження встановлено, що тривалий обтураційний холестаз призводить до вираженого звуження приносної (артеріол, прекапілярних артеріол), обмінної (гемокапілярів) ланок мікрогемоциркуляторного русла та розширення закапілярних венул і венул, венозного повнокров'я, гіпоксії, дистрофії, некробіозу клітин і тканин. Виявлена структурна перебудова мікросудин залежала від тривалості обтураційного холестазу.

КЛЮчОВІ СЛОВА: дванадцятипала кишка, гемомікроциркуляторне русло, обтураційний холестаз.
\end{abstract}

Вступ. Обтураційний холестаз (механічна жовтяниця) $€$ тяжким ускладненням захворювань органів гепатопанкреатобіліарної системи і нерідко зустрічається у клінічній практиці. Поширеність даної патології, труднощі її діагностики, лікування та профілактики, незадоволеність клініцистів результатами лікування поглиблюють актуальність вказаної проблеми. Варто зазначити, що невирішеними при цьому залишається ціла низка питань. Обтураційний холестаз супроводжується вираженими структурними змінами судинного русла органів і тканин [1-3]. При цьому судинні розлади є ранніми і мають характерні морфологічні ознаки. Відомо, що судинам гемомікроциркуляторного русла, де проходить транскапілярний обмін, належить важлива роль не тільки у трофічному забезпеченні тканин та клітин органів, але й у патоморфогенезі їх ушкоджень.

Необхідно зазначити, що особливості ремоделювання гемомікроциркуляторного русла дванадцятипалої кишки при обтураційному холестазі досліджені недостатньо [8]. Дванадцятипала кишка завжди втягується в патологічний процес при обтураційному холестазі, і в патогенезі різних ускладнень при вказаній патології структурні зміни ланок мікрогемоциркуляторного русла даного органа відіграють важливу роль $[4,5]$.

Метою дослідження стало вивчення особливостей структурної перебудови судин гемомікроциркуляторного русла дванадцятипалої кишки в різні строки обтураційного холестазу.

Матеріал і методи досліджень. В експерименті використано 16 статевозрілих свиней-самців в'єтнамської породи, які були поділені на 4 групи. 1 група склала 6 практично здорових свиней, яким здійснювали лапаротомії , 2 - 3 тварини, у яких забирали матеріал для дослідження через 3 доби механічної жовтяниці, 3 - 3 свині з 7 добовою механічною жовтяницею, 4-4 тварини з 28-денним обтураційним холестазом. Механічну жовтяницю моделювали за запропонованим нами способом [6]. Всі оперативні втручання про- водили в умовах тіопентало-натрієвого наркозу та з дотриманням правил асептики та антисептики. Евтаназію дослідних тварин проводили кровопусканням в умовах вказаного вище наркозу. Гемомікроциркуляторне русло дванадцятипалої кишки вивчали за допомогою ін'єкції її судин тушжелатиновою сумішшю. Туш-желатинову суміш вводили через черевну аорту. Через 3-4 години після заповнення кровоносного русла дванадцятипалої кишки вказаною вище сумішшю проводили забір її шматочків, які фіксували у 10,0 \% розчині нейтрального формаліну протягом 2 тижнів. На заморожуючому мікротомі виготовляли зрізи товщиною 30-40 мкм, які зневоднювали в етилових спиртах зростаючої концентрації, просвітлювали у метиленовому ефірі саліцилової кислоти і поміщали в полістирол. Виготовлені за такою методикою мікропрепарати вивчали за допомогою бінокулярного мікроскопа МБР-3 при різних збільшеннях. Із частини спостережень із заповненими судинами туш-желатиновою сумішшю виготовляли гістологічні мікропрепарати, забарвлені гематоксиліном-еозином. Морфометрично визначали діаметри артеріол, передкапілярних артеріол, гемокапілярів, закапілярних венул, венул, щільність судин гемомікроциркуля-

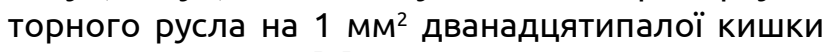
дослідних тварин [7]. Кількісні показники обробляли статистично. Обробка результатів виконана у відділі системних статистичних досліджень Тернопільського державного медичного університету імені І. Я. Горбачевського в програмному пакеті STATISTIKA. Різницю між порівнюваними величинами визначали за критерієм Стьюдента та Манна-Уїтні [8 ]. Необхідно зазначити, що проведені експериментальні дослідження та евтаназію дослідних тварин проводили з дотриманням «Загальних етичних принципів експериментів на тваринах", ухвалених Першим національним конгресом з біоетики (Київ, 2001) відповідно до «Європейської конвенції про захист хребетних 
Огляди літератури, оригінальні дослідження, погляд на проблему

тварин, що використовуються в дослідних та інших наукових цілях".

Результати й обговорення. Дані, отримані в результаті проведеного дослідження, представлені в таблиці 1.

Аналізом показаних у названій таблиці морфометричних параметрів встановлено, що вже через три доби після змодельованої патології досліджувані морфометричні параметри суттєво змінилися. При цьому діаметр артеріол у підслизовому прошарку дванадцятипалої кишки зменшився з $(18,25 \pm 0,30)$ до $(17,40 \pm 0,27)$ мкм. Наведені цифрові величини статистично достовірно $(p<0,05)$ між собою відрізнялися і останній морфометричний параметр виявився меншим за попередній на 4,65 \%. На сьому добу експерименту досліджуваний морфометричний показник був зниженим на 8,5 \% $(p<0,01)$ порівняно з аналогічним контрольним, а на 28 добу досліду досягав $(13,80 \pm 0,21)$ мкм. Вказаний вище морфометричний параметр з високим ступенем достовірності ( $<<0,001)$ відрізнявся від такого ж показника у 1 групі спостережень на 24,4 \%.

Майже аналогічна динаміка структурної перебудови виявлена при аналізі морфометричних показників передкапілярних артеріол у підслизовому прошарку дванадцятипалої кишки дослідних тварин. Так, через три доби після змодельованого обтураційного холестазу діаметр передкапілярних артеріол статистично достовірно $(p<0,05)$ зменшився майже на 6,0 \%, на 7 добу - на 10,9 \% ( $><0,01)$. У 4 групі спостережень (28 доба обтураційного холестазу) досліджуваний морфометричний параметр дорівнював $(6,90 \pm 0,09)$ мкм. Варто зазначити, що наведена цифрова величина 3 високою достовірністю $(p<0,001)$ відрізнялася від аналогічної у контрольних спостереженнях на $36,3 \%$.

Діаметр гемокапілярів у підслизовому прошарку дванадцятипалої кишки 1 групи тварин дорівню- вав $(6,15 \pm 0,12)$ мкм, а через 3 доби після змодельованого обтураційного холестазу $(5,82 \pm 0,09)$ мкм. Між наведеними морфометричними параметрами встановлена статистично достовірна $(p<0,05)$ різниця і останній показник виявився меншим за попередній на 5,36 \%. На 7 добу виявлена різниця між досліджуваними морфометричними параметрами дорівнювала 12,2 \% (р<0,01), а на 28 добу - 19,5 \% ( $<<0,001)$. Проаналізовані та наведені морфометричні параметри мікросудин свідчать, що приносна (артеріоли, передкапілярні артеріоли) та обмінна (гемокапіляри) ланки гемомікроциркуляторного русла дванадцятипалої кишки у всі строки змодельованого обтураційного холестазу виявилися звуженими. При цьому найвираженіший ступінь зменшення просвіту вивчених мікросудин спостерігався на 28 добу експерименту.

Проведеними морфометричними дослідженнями встановлено, що виносна частина (закапілярні венули і венули) мікрогемоциркуляторного русла дванадцятипалої кишки при змодельованій патології розширювалася. Так, через 3 доби після змодельованого експериментального обтураційного холестазу діаметр закапілярних венул у підслизовому прошарку досліджуваного органа збільшився з $(12,60 \pm 0,15)$ мкм до $(13,40 \pm 0,18)$ мкм, тобто на 6,3 \%. Варто також зазначити, що наведені вище морфометричні параметри статистично достовірно $(p<0,05)$ між собою відрізнялися. На 7 добу експерименту досліджувана різниця між вказаними морфометричними параметрами дорівнювала 18,5 \% ( $<<0,001)$, а на 28 добу - 35,7 \% ( $<<0,001)$. Аналогічно змінювалися також просвіти венул підслизового прошарку дванадцятипалої кишки при змодельованій патології. Так, через 3 доби від початку досліду діаметри (просвіти) венул статистично достовірно $(p<0,05)$ збільшилися на 5,8 \%, порівняно з контрольними величинами, на 7 добу - на 14,2 \% ( $<<0,001)$, на 28-у добу - на $30,2 \%(p<0,001)$.

Таблиця 1. Морфометрична характеристика мікрогемоциркуляторного русла дванадцятипалої кишки дослідних тварин $(\mathrm{M} \pm \mathrm{m})$

\begin{tabular}{|l|c|c|c|c|}
\hline \multicolumn{1}{|c|}{ Показник } & \multicolumn{4}{|c|}{ Група спостереження } \\
\cline { 2 - 5 } & 1 & 2 & 3 & 4 \\
\hline Діаметр артеріол, мкм & $18,25 \pm 0,30$ & $17,40 \pm 0,27^{*}$ & $16,70 \pm 0,24^{* *}$ & $13,80 \pm 0,21^{* * *}$ \\
\hline $\begin{array}{l}\text { Діаметр передкапілярних } \\
\text { артеріол, мкм }\end{array}$ & $10,84 \pm 0,15$ & $10,20 \pm 0,12^{*}$ & $9,66 \pm 0,12^{* *}$ & $6,90 \pm 0,09 * * *$ \\
\hline Діаметр гемокапілярів, мкм & $6,15 \pm 0,12$ & $5,82 \pm 0,09^{*}$ & $5,40 \pm 0,07^{*}$ & $4,95 \pm 0,06^{* * *}$ \\
\hline $\begin{array}{l}\text { Діаметр закапілярних венул, } \\
\text { мкм }\end{array}$ & $12,60 \pm 0,15$ & $13,40 \pm 0,18^{*}$ & $14,90 \pm 0,21^{* * *}$ & $17,10 \pm 0,24^{* * *}$ \\
\hline Діаметр венул, мкм & $26,80 \pm 0,36$ & $28,35 \pm 0,42^{*}$ & $30,60 \pm 0,42^{* * *}$ & $34,90 \pm 0,45^{* * *}$ \\
\hline $\begin{array}{l}\text { Щільність судин циркулятор- } \\
\text { ного русла }\end{array}$ & $3842,30 \pm 56,10$ & $3824,20 \pm 55,20$ & $3342,80 \pm 52,50 * *$ & $2785,10 \pm 51,60^{* * *}$ \\
\hline
\end{tabular}

Примітка. * - p<0,05; ** - p<0,01; *** - p<0,001, порівняно з 1 групою спостережень. 
Огляди літератури, оригінальні дослідження, погляд на проблему

Щільність мікросудин гемомікроциркулятор-

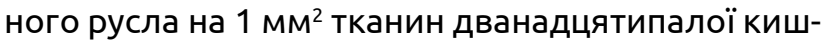
ки через 3 доби від початку досліду суттєво не змінювалася. На 7 добу експерименту спостерігалося виражене зниження щільності мікросудин на $13 \%(p<0,01)$, порівняно 3 аналогічним контрольним показником, а на 28 добу - на $27,5 \%$ $(p<0,001)$.

Отримані морфометричні показники досліджуваних судин свідчать, що обтураційний холестаз призводить до вираженої структурної перебудови судин мікрогемоциркуляторного русла дванадцятипалої кишки. При цьому необхідно також зазначити, що мікросудини приносної та обмінної ланок звужуються, а виносної частини мікрогемоциркуляторного русла - виражено розширюються. Виражене розширення закапілярних венул та венул призводило до венозного повнокров'я, яке обумовлювало набряк у судинних стінках та перивазальній стромі, що підтримувало та посилювало стан гіпоксії. Останнє сприяло збільшенню набряку і призводило до дистрофічних, некробіотичних змін клітин та тканин. Мікроскопічно венозні мікросудини гемомікроциркуляторного русла звивисті, розширені, з нерівномірним просвітом, з саккуляціями, повнокровні. У даних судинах місцями спостерігали стази, тромбози, діапедезні перивазальні крововиливи. Відмічалися у стінці дванадцятипалої кишки також осередки із зменшенням кількості мікросудин та безсудинні зони. Тромбози мікросудин, виникнення у них та перивазальних тканинах запального процесу призводили до блокування мікросудин, виключення частини їх з системи кровобігу, що вело до прогресування набряку, порушення транскапілярного обміну, деструкції та руйнування ендотеліоцитів. Ушкодження останніх призводило до зниження продукції оксиду азоту, підвищення синтезу ендотеліну-1, що посилювало спазм судин. Вказані гемомікроциркуляторні зміни супроводжувалися погіршанням реологічних властивостей крові, підвищенням проникності стінок мікросудин, плазморагії не тільки їх стінок, а й паравазальної строми білками крові. При цьому посилюються перивазальний набряк, насичення навколишньої строми білками та форменими елементами крові, гіпоксія, розволокнення, дезорганізація та дисоціація волокнистих структур, суттєво погіршується дифузія поживних речовин та кисню, що ускладнюється дистрофічними та некробіотичними змінами стромальних та м'язових елементів, фібропластичною активністю: полімеризацією та насиченням колагенових фібрил глікозоаміногліканами $[1,9]$. Все це призводило до склерозування строми, збільшення розмежування компонентів гемомікроциркуляторного русла та вираженішого посилення гіпоксії.

Гістологічно у стінці дванадцятипалої кишки виявилися виражені судинні розлади, набряк строми, вогнища дистрофічно і некробіотично змінених епітеліоцитів і ендотеліоцитів, осередки інфільтрації, проліферація ендотеліоцитів. Останнє підтверджувало наявність гіпоксії $[4,5$, 9]. Спостерігалися також набряк ендотеліоцитів, просякання їхньої мембрани білками плазми, дистрофія і некроз цих клітин. У деяких судинах спостерігались вогнища фібриноїдного набухання та некроз, що свідчило про їхнє виражене пошкодження.

Висновок. Обтураційний холестаз призводить до структурної перебудови судин мікрогемоциркуляторного русла дванадцятипалої кишки, яка характеризується вираженим звуженням приносної (артеріол, передкапілярних артеріол), обмінної (гемокапілярів) ланок мікрогемоциркуляторного русла та розширенням закапілярних венул і венул, венозним повнокров'ям, гіпоксією, дистрофії, некробіозом клітин і тканин. Вираженість структурної перебудови судин мікрогемоциркуляторного русла дванадцятипалої кишки залежить від тривалості обтураційного холестазу.

Перспективи подальших досліджень. Всебічне адекватне вивчення структурної перебудови судин мікрогемоциркуляторного русла дванадцятипалої кишки в умовах обтураційного холестазу дозволить суттєво розширити діагностику, корекцію та профілактику досліджуваної патології.

\section{ЛІТЕРАТУРА}

1.Бахтин В. А. Хирургическая тактика лечения больных со злокачественными опухолями внепеченочных желчных протоков, осложненными механической желтухой / В. А. Бахтин, В. А. Янченко, С. М. Аракелян // Вестн. Ивановской медицинской академии. - 2007. - Т. 12, № 3-4. - С. 77-78.

2. Быков А. Д. Сравнительная эффективность методов дренирования внепечёночных желчных протоков при механической желтухе / А. Д. Быков, Д. А. До- роган // Вестн. Бурятского государственного университета. - 2009. - № 12. - С. 152 - 154.

3. Пилипчук В. І. Варіанти операційних втручань на жовчовивідних протоках при хронічному панкреатиті 3 ознаками біліарної гіпертензії / В. І. Пилипчук // Шпитальна хірургія. - 2016. - № 2. - С. 27-31.

4. Жорняк П. В. Морфологічні зміни в дванадцятипалій кишці після виконання різних методів резекції шлунка / П. В. Жорняк, Г. Я. Костюк, П. К. Загниборода // 
Огляди літератури, оригінальні дослідження, погляд на проблему

Вісник проблем біології і медицини. - 2007. - № 1. C. $120-123$.

5. Гнатюк М. С. Морфометрична оцінка вікових особливостей ремоделювання артерій дванадцятипалої кишки / М. С. Гнатюк, Л. В. Татарчук, М.В.Данів // Клінічна анатомія та оперативна хірургія. - 2009. - Т. 8, № 4 (30). - C. 54-57.

6. Патент UA78273, MПK G 09B23/28(2006/01) Спосі6 моделювання механічної жовтяниці / М. С. Гнатюк № U201211327; заявл.01.10.2012; опубл.11.03.2013, Бюл. № 5.
7. Автандилов Г. Г. Основы количественной патологической анатомии / Г. Г. Автандилов. - М. : Медицина, 2002. $-240 \mathrm{c}$.

8. Лапач С. Н. Статистические методы в медико-биологических исследованиях Excell / C. Н. Лапач, А. В. Губенко, П. Н. Бабич. - К. : Морион, 2001. - 410 с.

9.Sobazstiano P. Pathophysiology of Chronic Damage/ P. Sobazstiano, F. di Molat // Acute and Chronic Pancreatitis, Turin : Editioni Minerva modica, 2013. - P. 63-69.

\title{
PECULIARITIES OF STRUCTURAL RECONSTRUCTION OF MICROHEMOCIRCULATORY BED VESSELS OF DUODENUM AT THE OBTURATIVE CHOLESTASIS
}

\author{
@M. S. Hnatiuk, L. V. Tatarchuk, S. O. Hrabchak
}

\section{Horbachevsky Ternopil State Medical University}

SUMMARY. The results of study of vessels of structural reconstruction of microhemocirculatory duodenum bed at the obstructive cholestasis are presented in the article. As a result of the conducted experience it was established that obstructive cholestasis caused narrowing arteriols, precapillaries, capillaries, widening postcapillaries, venuls, venous full-blooded, hypoxia, dystrophic and necrobiotic changers of cells and tissues. The degree of microvessels structural changes depended on continuance of the obstructive cholestasis.

KEY WORDS: duodenum, microhemocirculatory bed, obstructive cholestasis. 